\title{
Isolation, Characterization and Antitumor Effect on DU145 Cells of a Main Polysaccharide in Pollen of Chinese Wolfberry
}

\author{
Fei Chen ${ }^{1, \dagger}{ }^{,}$Linwu $\operatorname{Ran}^{1,2, *, \dagger}$, Jia $\mathrm{Mi}^{3}$, Yamei $\operatorname{Yan}^{3, *}, \mathrm{Lu} \mathrm{Lu}^{3}$, Bo Jin ${ }^{3}$, Xiaoying $\mathrm{Li}^{3}$ \\ and Youlong $\mathrm{Cao}^{3}$ \\ 1 College of Public Health and Management, Ningxia Medical University, Yinchuan 750004, China; \\ chenfei150113@163.com \\ 2 Laboratory Animal Center, Ningxia Medical University, Yinchuan 750004, China \\ 3 Institute of Wolfberry Engineering Technology, Ningxia Academy of Agriculture and Forestry Sciences, \\ Yinchuan 750002, China; lorna0102@126.com (J.M.); lulubing8901@163.com (L.L.); \\ 15509585650@163.com (B.J.); 1xy_2002_79@163.com (X.L.); youlongchk@163.com (Y.C.) \\ * Correspondence: rlw@nxmu.edu.cn (L.R.); yanyamei@163.com (Y.Y.); \\ Tel.: +86-0951-698-0195 (L.R.); +86-0951-688-6783 (Y.Y.) \\ + These authors contributed equally to this work.
}

Received: 16 August 2018; Accepted: 17 September 2018; Published: 21 September 2018

\begin{abstract}
Modern studies have shown that pollen has a certain role in the treatment of prostate-related diseases. In the present study, pollen polysaccharides from Chinese wolfberry (WPPs) were extracted by hot-water extraction and ethanol precipitation, further purified by chromatography on a DEAE-cellulose column and Sephadex G-100 column. Homogeneous polysaccharide CF1 of WPPS was obtained, the molecular weight of which was estimated to be $1540.10 \pm 48.78 \mathrm{kDa}$ by HPGPC-ELSD. HPLC with PMP derivatization analysis indicated that the monosaccharide compositions of $\mathrm{CF} 1$ were mannose, glucuronic acid, galacturonic acid, xylose, galactose, arabinose, and trehalose, in a molar ratio of 0.68:0.59:0.27:0.24:0.22:0.67:0.08. The antitumor effects of CF1 upon MTT, Tunel assay and flow cytometry assay were investigated in vitro. The results showed that CF1 exhibited a dose-dependent antiproliferative effect, with an IC50 value of $374.11 \mu \mathrm{g} / \mathrm{mL}$ against DU145 prostate cancer cells. Tunel assay and flow cytometry assay showed that the antitumor activity of CF1 was related to apoptosis in vitro. The present study suggested that the CF1 of WPPs might be a potential source of antitumor functional food or agent.
\end{abstract}

Keywords: Chinese wolfberry; pollen polysaccharides; purification; antitumor activity

\section{Introduction}

Prostate cancer is an epithelial malignancy that occurs in the prostate and is a malignant tumor with a high incidence in the male genitourinary system. Although treatments such as surgery, radiochemotherapy or androgen ablation have improved the survival rate of patients, a cure remains elusive, with resistance developing over time [1]. Therefore, finding a low-toxic and effective anti-cancer drug from natural compounds has become a hot topic in cancer treatment. Pollen has been used as a "perfect health food" for many centuries due to its abundance of nutrimental constituents and bioactive compounds [2]. It contains a variety of natural products such as polysaccharides, phytosterols, flavone, terpenoids and saponins. In the 1990s, studies reported that pollen water extract Cernitin T-60 could inhibit the growth of prostate cancer cells DU-145 and LNCap [3]. Modern research has also shown that pollen possesses therapeutic effects [4]. Pollen of flowers is a natural product with a long history of use in China and Europe as a well-tolerated treatment for 
prostate-related diseases such as benign prostatic hyperplasia and prostatitis [5]. Polysaccharides are one of the main active ingredients of pollen. Much research has indicated that polysaccharides from pollen significantly inhibit tumor growth and enhance immunomodulating activity [6-10]. Chinese wolfberry is a traditional Chinese medicine used for both medicine and food. Modern research shows that it has many functions, such as improving the immune function, anti-oxidation, anti-aging, antitumor and liver protection [11,12]. At present, much research is dedicated to the study of the polysaccharides from wolfberries, like antitumor activities on tumor cells such as those in the respiratory, reproductive, urinary and digestive systems [13-16]. However, little is known about the antitumor properties of polysaccharides from wolfberry pollen. Therefore, in this study, we isolated polysaccharides from wolfberry pollen (WPPs) and analyzed their monosaccharide compositions and molecular weights. Then, the in vitro antitumor activities of isolated polysaccharides were evaluated by 3-(4,5-dimethylthiazol-2-yl)-2,5-diphenyltetr-razolium bromide (MTT), Tunel assay and flow cytometry assay in DU145 prostate cancer cells. To the best of our knowledge, this is the first study to investigate the antitumor activity of pollen polysaccharides from the Chinese wolfberry.

\section{Results}

\subsection{Extraction, Isolation and Purification of WPPs}

Hot water extraction and ethanol precipitation methods were carried out to extract crude WPPs. Subsequently, purification of the crude WPPs was performed by DEAE cellulose- 52 column, and they were eluted with gradients of $0,0.1,0.3,0.5,0.7$, and $0.8 \mathrm{~mol} / \mathrm{L} \mathrm{NaCl}$ solutions. The fractions of the isolated WPPs were mainly concentrated in the elution solution. As shown in Figure 1, six components were separated and obtained from WPPs. Among these, the content of C3 was the highest, so the C3 component was selected and further purified by the Sephadex G-100 column.

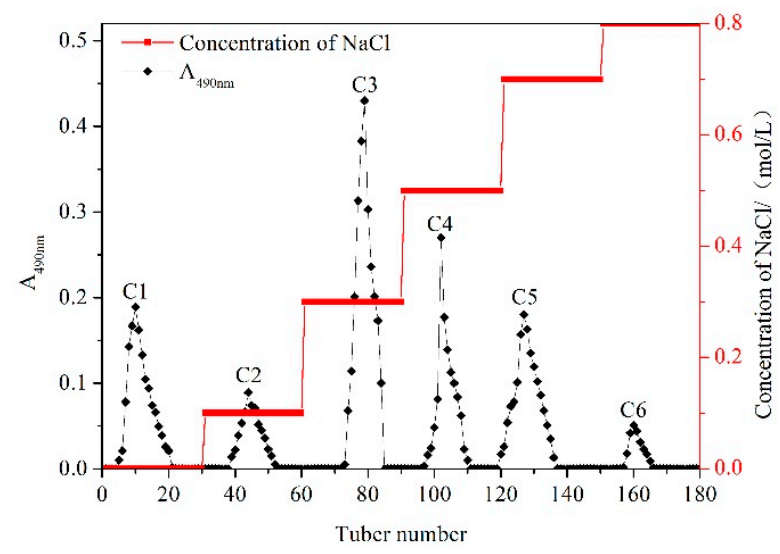

Figure 1. Gradient elution profile of polysaccharides extracted from Chinese wolfberry pollen by DEAE cellulose-52 chromatography.

\subsection{Further Purification by Sephadex G-100 Column}

The separated C3 fraction of the WPPs was further purified using a Sephadex G-100 column. The results are shown in Figure 2. One component further separated and purified by the Sephadex G-100 column was a single eluting symmetrical peak, indicating that the obtained polysaccharide was a relatively homogeneous polysaccharide. After dialysis and lyophilization of the collected solution of this component, a pure polysaccharide CF1 was obtained.

\subsection{Analysis of Molecular Weight and Monosaccharide Composition of CF1 of WPPs}

The molecular weight of the CF1 of WPPs was determined using High-Performance Gel permeation Chromatography-Evaporative Light Scattering Detector (HPGPC-ELSD). The molecular 
weight of $\mathrm{CF} 1$ is shown in Figure 3; the elution peak of the CF1 isolated and purified from the polysaccharide C3 was single and symmetrical. It was shown that the CF1 isolated and purified by the two columns was separated. The retention time of the CF1 component was $6.961 \mathrm{~min}$. The molecular weight (MW) calculated on the basis of the standard pullulan molecular weight curve was $1540.10 \pm 48.78 \mathrm{kDa}$. The monosaccharide compositions of CF1 were analyzed by PMP derivatization, and consisted of mannose, glucuronic acid, galacturonic acid, xylose, galactose, arabinose, and trehalose in a molar ratio of 0.68:0.59:0.27:0.24:0.22:0.67:0.08 (Figure 4), indicating that it was a kind of heteropolysaccharide.

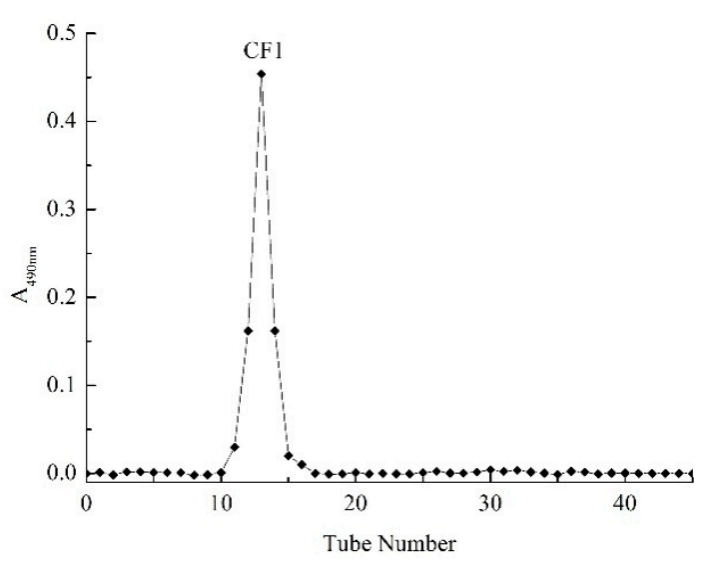

Figure 2. Elution profile of polysaccharide CF1 by Sephadex G-100 column chromatography.

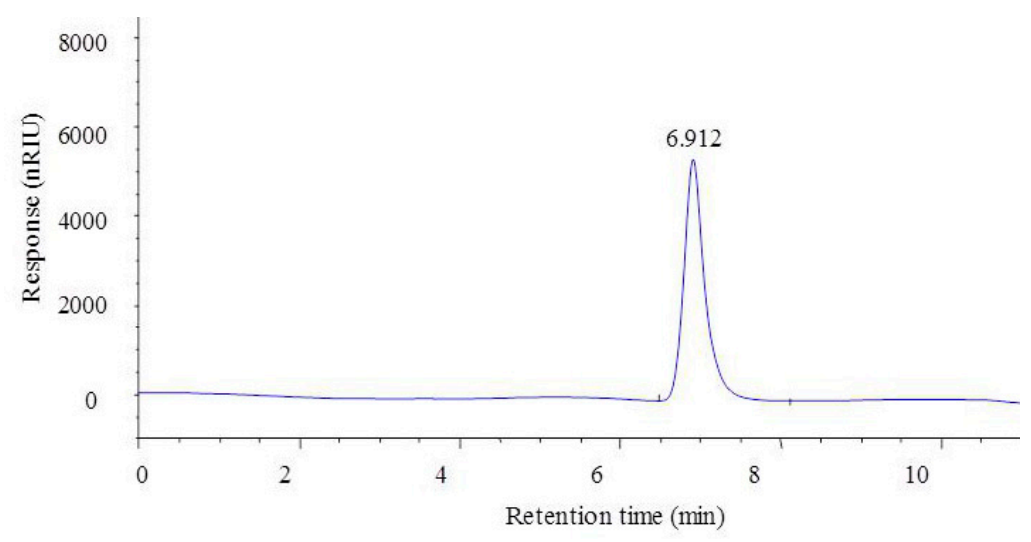

Figure 3. HPLC spectra of $\mathrm{CF} 1$ purified from the $\mathrm{C} 3$ fraction of the WPPs.

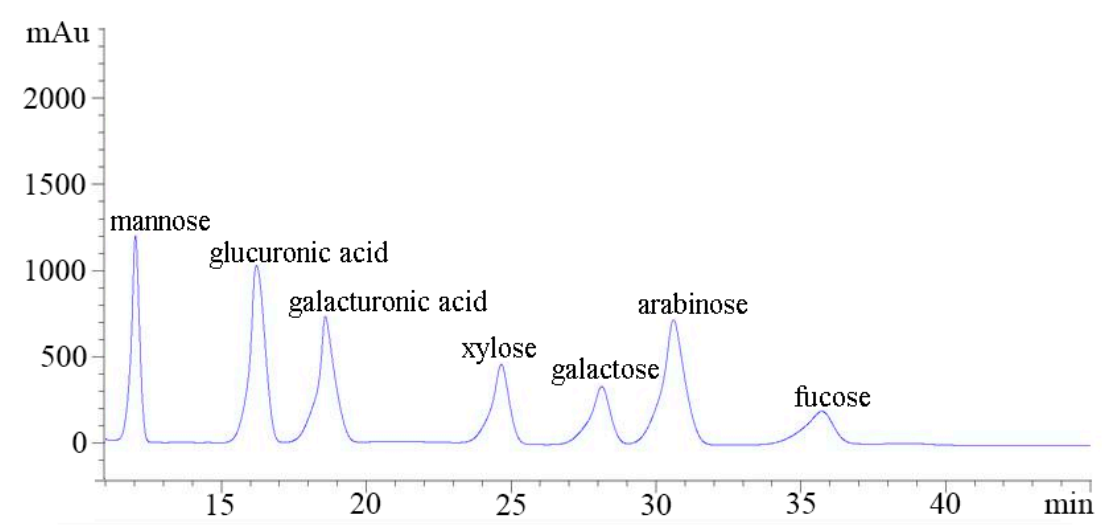

Figure 4. HPLC spectra of monosaccharide compositions of CF1. 


\subsection{Effects of CF1 of WPPs on the Proliferation of DU145 Cells}

In this study, we used an MTT assay to measure the proliferation rate of DU145 cells. As shown in Figure 5a, there was a significant decrease in the proliferation of cells with increasing doses of CF1 $(p<0.05)$. The relative proliferation rates of the DU145 cells were $85.3 \%, 72.0 \%$ and $33.6 \%$, respectively, after treatment with CF1 $(125,250$, and $500 \mu \mathrm{g} / \mathrm{mL})$ for $24 \mathrm{~h}$. The CF1 of WPPs inhibited the growth of DU145 cells, with an IC50 value of $374.11 \mu \mathrm{g} / \mathrm{mL}$. As shown in Figure 5b, the morphology of cells was observed under an inverted microscope. In the control group, cells well adhered to the wall and grew firmly, showing an elliptical shape and cell density. In contrast, cells treated with CF1 at the concentrations of 125,250 , and $500 \mu \mathrm{g} / \mathrm{mL}$ became round, could not be affixed to the walls, and floated in the medium. The number of cells treated with CF1 also decreased compared to the control group. The morphological changes of DU145 cells were consistent with results of MTT assay. These results indicated that the CF1 of WPPs significantly inhibited the proliferation of DU145 cells in a dose-dependent manner.

(a)

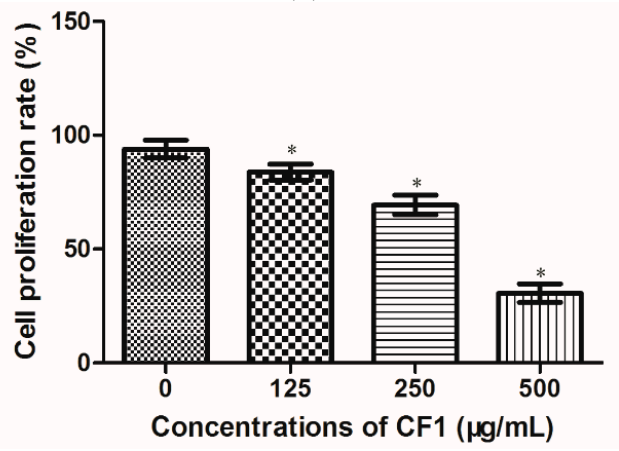

(b)

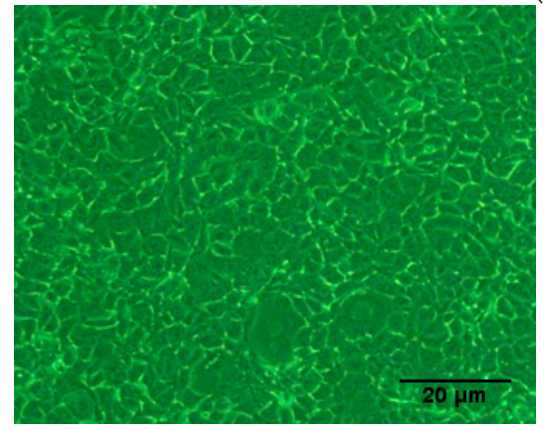

$0 \mu \mathrm{g} / \mathrm{mL}$

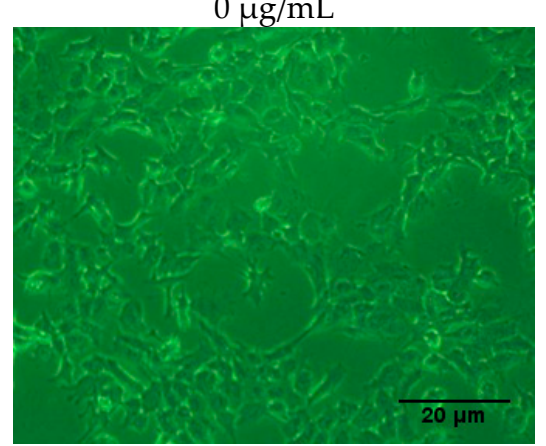

$250 \mu \mathrm{g} / \mathrm{mL}$

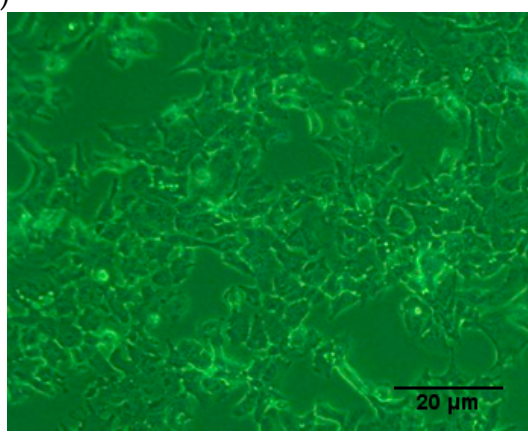

$125 \mu \mathrm{g} / \mathrm{mL}$

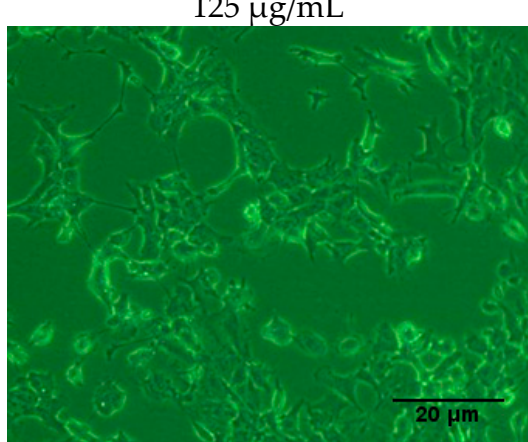

$500 \mu \mathrm{g} / \mathrm{mL}$

Figure 5. Effects of the CF1 of WPPs on the proliferation of DU145 cells. (a) DU145 cells were treated with 0, 125, 250, $500 \mu \mathrm{g} / \mathrm{mL}$ CF1 of WPPs in Dulbecco's Modified Eagle's Medium (DMEM) containing $10 \%$ FBS for $24 \mathrm{~h}$, and the proliferation rate was measured by an MTT assay. The data are presented as the mean $\pm \mathrm{SD}(n=3),{ }^{*}$ indicates a significant difference, $(p<0.05)$. (b) Morphological changes of DU145 cells treated with different concentrations of CF1 for $24 \mathrm{~h}$. 


\subsection{Effects of the CF1 of WPPs on the Apoptosis Induction of DU145 Cells}

Apoptosis is considered a major cause of cell growth inhibition. To investigate whether the CF1 of WPPs' suppression of DU145 cells proliferation is attributable to apoptosis, we used a Tunel assay to observe apoptosis in DU145 cells. In the event of apoptosis, endogenous DNA endonuclease activation causes DNA fragmentation and $3^{\prime}-\mathrm{OH}$ exposure. Exposure of $3^{\prime}-\mathrm{OH}$ can be labeled deoxynucleotide, which can be displayed in situ by fluorescence. The nucleus of the apoptotic cells that were stained with Tunel showed green fluorescence, and DAPI-stained nuclei showed blue fluorescence. Therefore, the apoptotic cells were blue-green in the merged fluorescence of the two-color fluorescence. A certain number of apoptotic cells were seen in each CF1 treatment group, and as the concentration increased, the number of apoptotic cells increased (Figure 6b). These results of the Tunel assay suggested that the CF1 of WPPs could induce the apoptosis of DU145 cells.

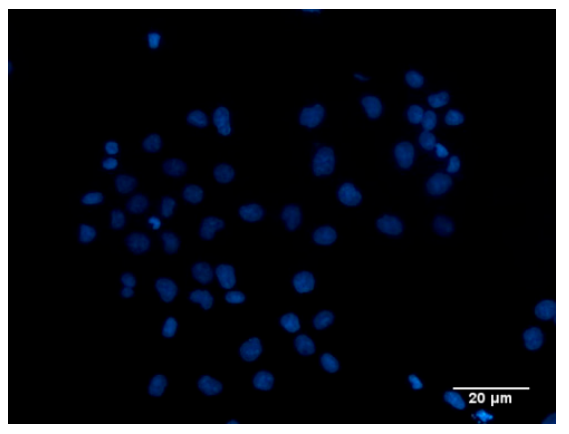

$0 \mu \mathrm{g} / \mathrm{mL}$

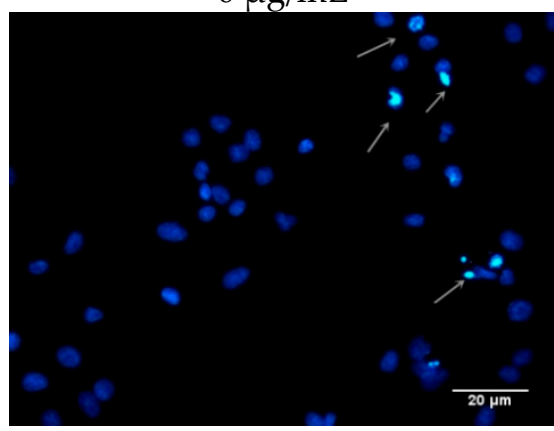

$250 \mu \mathrm{g} / \mathrm{mL}$ (a)

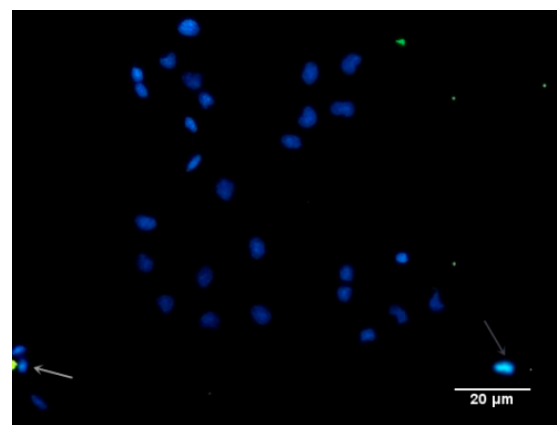

$125 \mu \mathrm{g} / \mathrm{mL}$

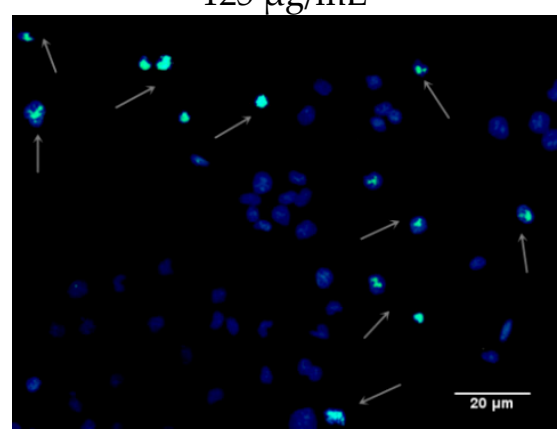

$500 \mu \mathrm{g} / \mathrm{mL}$

(b)

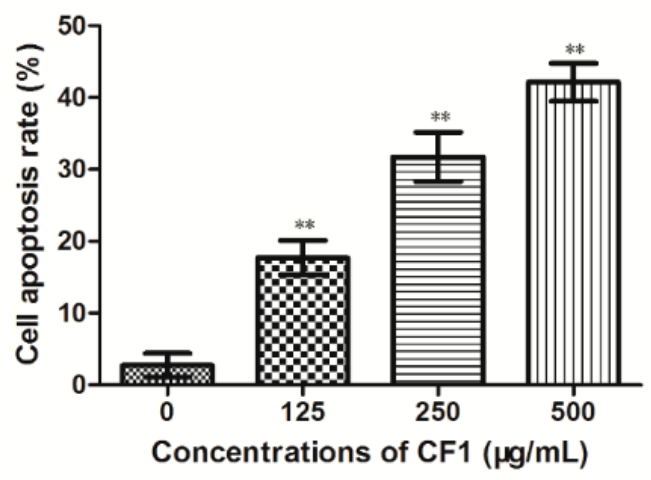

Figure 6. Cont. 


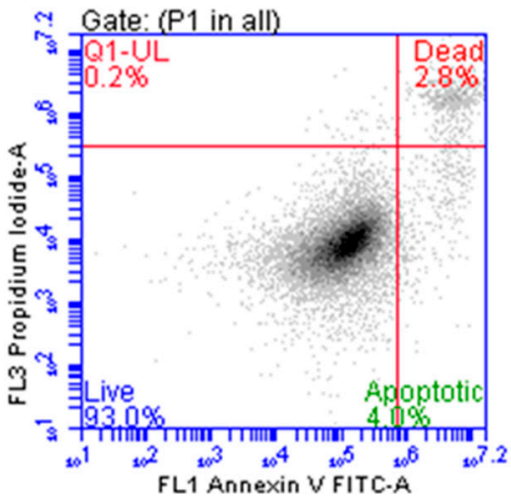

$0 \mu \mathrm{g} / \mathrm{mL}$

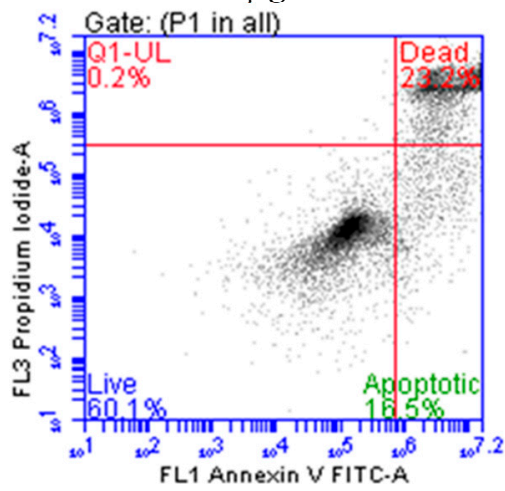

$250 \mu \mathrm{g} / \mathrm{mL}$ (c)

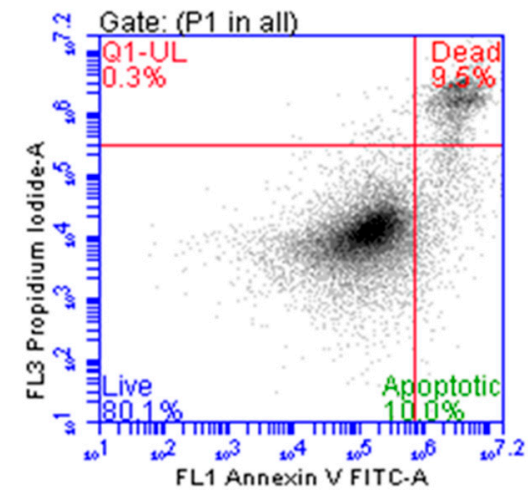

$125 \mu \mathrm{g} / \mathrm{mL}$

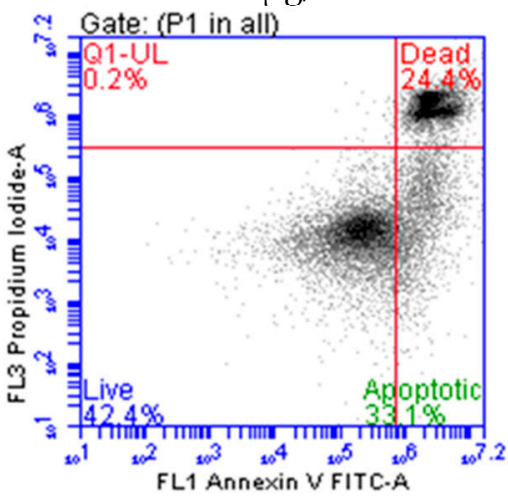

$500 \mu \mathrm{g} / \mathrm{mL}$.

(d)

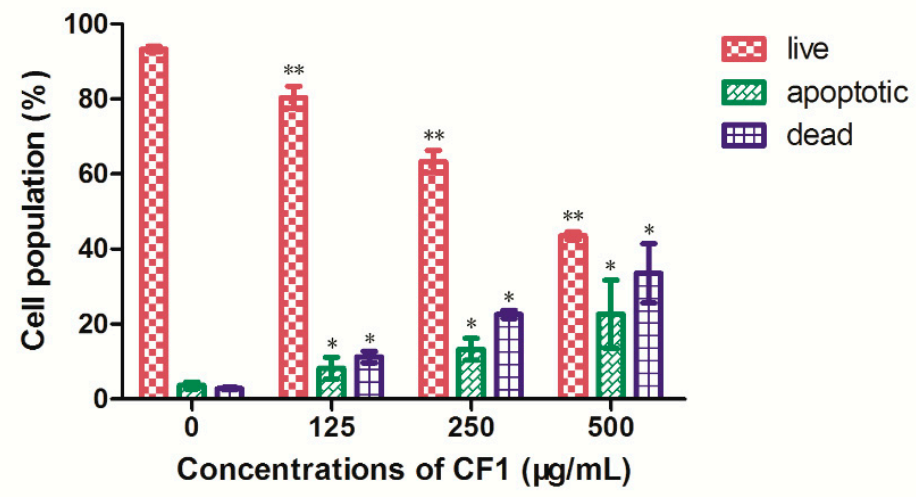

Figure 6. Induction of apoptosis in DU145 cells by CF1 of WPPs. (a) Apoptosis in DU145 cells detected by TUNEL assay. DU145 cells were treated with CF1 at concentrations of $0,125,250,500 \mu \mathrm{g} / \mathrm{mL}$ for $24 \mathrm{~h}$ and were then subjected to Tunel assay and imaged by microscopy. The condensed and fragmented nuclei are indicated with arrows. (b) Cell apoptosis rate is expressed as the mean $\pm \mathrm{SD}$ $(n=3){ }^{*} p<0.05 ;{ }^{* *} p<0.01$ compared with the control. (c) Apoptosis in DU145 cells detected by flow cytometry. (d) The data are presented as the mean $\pm \operatorname{SD}(n=3) .{ }^{*} p<0.05,{ }^{* *} p<0.01$ compared with the control.

Furthermore, we also used flow cytometry to measure distribution of cells in an early and the later stages of the apoptosis. As seen in Figure $6 c, d$, the CF1 of WPPs significantly induced apoptosis in DU145 cells in a dose-dependent manner. The induction of apoptosis rates in DU145 cells were $10.0 \%, 16.5 \%$ and $33.1 \%(p<0.05)$, respectively, after treatment with CF1 $(125,250$, and $500 \mu \mathrm{g} / \mathrm{mL})$ for $24 \mathrm{~h}$. The results of the live and dead assay of DU145 cells were consistent with the results of the 
apoptosis assay. These results suggested that the CF1 of WPPs inhibited the growth of DU145 prostate cancer cells through induction of apoptosis.

\section{Discussion}

Pollen not only contains various nutrient chemical components, but also contains complex bioactive substances such as polysaccharides, flavonoids, saponins, and phytosterols. Modern studies have shown that pollen still has a certain role in the treatment of diseases, especially in antitumor, anti-oxidation, lipid-lowering, anti-inflammatory $[4,17,18]$. Polysaccharides are one of the main active components of pollen. Polysaccharides have been reported to possess a broad spectrum of biological activities, particularly antitumor [19-22] and immunomodulating activities [23-26].

Previous studies have indicated that different extraction methods have effects on the structure and bioactivity of polysaccharides. A study by D. Cör et al. revealed that the antioxidant activity of polysaccharide-protein complexes attained by ultrasound-assisted extraction was generally higher than with the conventional hot-water method [27]. Zhu et al. confirmed that hot-water extraction also had a higher extraction efficiency [28]. Thus, it would be interesting to pursue a further study of extraction methods with regard to the yield and antitumor activity of pollen polysaccharides from Chinese wolfberry. The polysaccharide is composed of more than 10 monosaccharide residues polymerized by glycosidic bonds. Different kinds of polysaccharides contain different types of monosaccharides, different degrees of polymerization, different properties of glycosidic bonds, and its different MWs will lead to differences in the physical properties and biological activity of the polysaccharides. Generally, higher MW molecular weight is associated with greater antitumor activity [29]. Moreover, polysaccharides with higher MW had a more complex structure and composition [30]. In this study, the molecular weight of CF1 component was estimated to be $1540.10 \pm 48.78 \mathrm{kDa}$. In addition, several observations have suggested that the monosaccharide compositions of the polysaccharides could affect their antitumor activity [31,32]. Moreover, polysaccharides with $\beta$-glucan such as $(1 \rightarrow 3)$-linked- $\beta$-D-glucose backbone chain exert a relatively higher anti-proliferation activity [33]. Our results of monosaccharide compositions of CF1 were similar to those findings.

Human prostate cancer cell lines are composed of hormone-sensitive and -insensitive cells. LNCaP is a human androgen-dependent prostatic cancer cell line. DU145 and PC-3 cells are hormone insensitive. In this study, human prostate cancer cell line DU145 was chosen to evaluate the proliferation effects of CF1 of WPPs in vitro using the MTT method. The results indicated that CF1 of WPPs possessed growth inhibition effects against DU145 cells, and the proliferation rate exhibited a dose-dependent behavior. These results are consistent with previous research in following by treatment with paeonol [34] and fucoidan [35]. The cytotoxic effects of wolfberry polysaccharides have previously been reported on several tumor cell lines, including PC-3 and DU-145 (prostate cancer cells) [36], SW480 and Caco-2 (colon cancer cells) [13], and QGY7703 (hepatoma cells) [37]. Nevertheless, there have been no reports on the antiproliferative properties of WPPs.

Apoptosis is a kind of programmed cell death. Once this regulatory mechanism is broken, it will lead to the occurrence of disease, tumors and even death. Therefore, inducing apoptosis and inhibiting cancer progression has become a new perspective on the treatment of cancer. To determine whether DU145 cells treated with CF1 of WPPs underwent apoptosis, Tunel assay and flow cytometry were used to observe apoptotic cells. Our results showed that the CF1 of WPPs also significantly induced apoptosis in DU145 cells in a dose-dependent manner in vitro. Furthermore, we confirmed that the antitumor effects of the CF1 of WPPs were related to induction of apoptosis and death of DU145 cells by flow cytometry assay. Induction of apoptosis is one important mechanism by which an antitumor agent acts [38]. Some previous research has demonstrated that polysaccharides induce the apoptosis of cancer cells by promoting the expression levels of cleaved poly ADP-ribose polymerase (PARP) and caspase-3 [39-41]. Therefore, it is worthwhile to have a further study of the mechanism for the effects of CF1 on DU145 prostate cancer cell apoptosis. 


\section{Materials and Methods}

\subsection{Materials and Reagents}

The wolfberry pollen was collected from the Ningxia Academy of Agriculture and Forestry Sciences (Yinchuan, Ningxia, China). Cellulose DEAE-52, Sephadex G-100 columns and monosaccharide standards (mannose, glucuronic acid, galacturonic acid, xylose, galactose, arabinose, and trehalose) were purchased from Sigma Chemical Co., Ltd. (St. Louis, MO, USA). HPLC-grade acetonitrile was purchased from TEDIA Co., Inc. (Fairfield, IA, USA). 1-phenyl-3-methyl-5-pyrazolone (PMP) high-glucose DMEM medium and fetal bovine serum were purchased from Gibco (Carlsbad, CA, USA). Penicillin-streptomycin double antibody and $0.25 \%$ trypsin were purchased from Solarbio Science \& Technology Co., Ltd. (Beijing, China). 3-(4,5-dimethylthiazol-2-yl)-2,5-diphenyltetrazolium bromide (MTT) was purchased from KeyGEN BioTech Co., Ltd. Nanjing, China). In situ cell death detection kit and POD were purchased from Roche Diagnostics (Indianapolis, IN, USA) and DAPI was obtained from ZSGB-BIO Biological Co., Ltd. (Beijing, China). Annexin V-FITC cell apoptosis detection kit was purchased from Best Bio Biological Co., Ltd. (Shanghai, China).

\subsection{Extraction of Crude WPPs}

The preparation of wolfberry pollen was carried out according the reported method [42] with some modifications. The procedure of extraction was as follows:

Firstly, $200 \mathrm{~g}$ of wolfberry pollen was crushed and extracted using five-fold volume of petroleum ether at room temperature for $5 \mathrm{~h}$, and the organic layer was removed by chromatography paper filtration, then the residue was extracted by five-fold volume of deionized water for 3 times, each time for $2 \mathrm{~h}$. The extraction temperature was $45{ }^{\circ} \mathrm{C}$ The combined aqueous extracts were filtered by chromatography paper and concentrated by a four-fold volume of anhydrous ethanol at $4{ }^{\circ} \mathrm{C}$ overnight. The precipitates were collected by centrifugation at $4000 \mathrm{rpm}$ for $15 \mathrm{~min}$, dissolved in $5 \mathrm{~mL}$ deionized water and dialyzed for $48 \mathrm{~h}$. At last, the extract was decompressed by rotary evaporator (Shanghai Yarong Biochemical Instrument Factory, Shanghai, China) at temperature below $45^{\circ} \mathrm{C}$ and then freeze-dried for $24 \mathrm{~h}$ to obtain crude WPPs.

\subsection{Purification of Crude WPPs by DEAE Cellulose-52 Column}

Crude WPPs (100 mg) were dissolved in deionized water $(20 \mathrm{~mL})$, and this solution was slowly added to the well-balanced DEAE cellulose-52 column using a dropper along the column wall. Gradient elution was sequentially performed with $0,0.1,0.3,0.5,0.7$ and $0.8 \mathrm{~mol} / \mathrm{L} \mathrm{NaCl}$ solutions at a flow rate of $1 \mathrm{~mL} / \mathrm{min}$, and 20 tubes were collected per gradient for $10 \mathrm{~min}$ each. The phenol-sulfate acid method was used to detect the polysaccharide content, and the elution curve was plotted according to the content. Firstly, different volume $(0,0.2,0.4,0.6,0.8,1 \mathrm{~mL})$ glucose solution were took into the tubes and added water to $2 \mathrm{~mL}$; secondly, $1 \mathrm{~mL}$ of $6 \%$ phenol solution and $5 \mathrm{~mL}$ of concentrated sulfuric acid were added to those tubes, reacted for $20 \mathrm{~min}$, and then measured the absorbance at $490 \mathrm{~nm}$. The sample with the highest polysaccharide content was selected, collected and concentrated by rotary evaporator (below $45^{\circ} \mathrm{C}$ ). The salt was removed by dialysis and then lyophilized.

\subsection{Further Purification by Sephadex G-100 Column}

The polysaccharide fraction obtained in the previous step was mixed with $10 \mathrm{~mL}$ of a $5 \mathrm{mg} / \mathrm{mL}$ solution in deionized water and slowly added to the equilibrated Sephadex G-100 column. Elution was performed with deionized water at a rate of $0.3 \mathrm{~mL} / \mathrm{min}$, and elution fractions were automatically collected, $10 \mathrm{~mL}$ per tube. The Phenol-sulfate acid method was used to detect the absorbance of the collected samples and to draw the elution gradient curve. The sample with the highest polysaccharide content was selected and collected by a rotary evaporator, concentrated, dialyzed, desalted and lyophilized to obtain pure WPPs. 


\subsection{Analysis of Monosaccharide Composition of CF1 of WPPs}

The monosaccharide composition was determined by HPLC by the described method of pre-column derivatization with PMP [43]. The specific methods were as follows: Firstly, the monosaccharide standards were mixed into a mixed aqueous solution (the concentration of each monosaccharide was $5 \mathrm{mg} / \mathrm{L}$ ). $50 \mu \mathrm{L}$ of the mixed standard monosaccharide solution was pipetted into $50 \mu \mathrm{L} 0.6 \mathrm{M} \mathrm{NaOH}$ solution and mixed well. Then the mixture $(100 \mu \mathrm{L})$ was labeled with 1-phenyl-3-methyl-5-pyrazolone (PMP) by adding $100 \mu \mathrm{L}$ of $0.5 \mathrm{M}$ methanol solution of PMP. The following reaction took place in a $75^{\circ} \mathrm{C}$ constant-temperature blast oven for $110 \mathrm{~min}$, at which point it was then removed and cooled down. $0.3 \mathrm{M}$ hydrochloric acid $(100 \mu \mathrm{L})$ was added for neutralization and then evaporated. Next, the extraction was performed three times with chloroform. The aqueous layer was filtered through a $0.22 \mu \mathrm{m}$ membrane and analyzed by HPLC.

To the polysaccharide sample solution $(100 \mu \mathrm{L}, 2 \mathrm{mg} / \mathrm{mL})$ was added $4 \mathrm{M}$ trifluoroacetic acid (TFA, $100 \mu \mathrm{L})$ to hydrolyze at $110{ }^{\circ} \mathrm{C}$ for $2 \mathrm{~h}$. After hydrolysis, methanol solution $(200 \mu \mathrm{L})$ was added to remove excess TFA, and then evaporated at reduced pressure. This procedure was repeated again to remove the TFA. The residue was dissolved in $100 \mu \mathrm{L}$ of $0.3 \mathrm{M} \mathrm{NaOH}$ solution. Then $100 \mu \mathrm{L}$ of $0.5 \mathrm{M}$ methanol solution of PMP was added to the mixed solution and the reaction was carried out at $70{ }^{\circ} \mathrm{C}$ for $100 \mathrm{~min}$. After cooling, the solution was neutralized, extracted, and filtered using a $0.22 \mu \mathrm{m}$ membrane in the same manner as that used for the mixed standard monosaccharide solution.

\subsection{Determination of the MolecularWeight of CF1 of WPPS}

High-performance gel permeation chromatography (HPGPC, TSK G4000PWXL column $7.8 \times 300 \mathrm{~mm}$, Tosoh Crop, Tokyo, Japan)_Evaporative Light Scattering Detector (ELSD) was used to measure the molecular weight of the polysaccharide fraction after two stepwise purifications of DEAE cellulose-52 and Sephadex G-100. In addition, distilled water was used as the mobile phase, the flow rate was $0.8 \mathrm{~mL} / \mathrm{min}$, and the temperature of the column was $35^{\circ} \mathrm{C}$. At the same time, the pullulan polysaccharide standards whose molecular weight range was close to that of the samples were selected (the molecular weight was 20,100, 200,400, 800, $1600 \mathrm{kDa}$ ) as a standard curve, according to the standard curve to obtain a linear regression equation as follows: $y=-0.5423 x+9.734 .435\left(R^{2}=0.9973\right)$; $y$ is the logarithm of the molecular weight of the polysaccharide; $x$ is the retention time of the pollen polysaccharide ( $\mathrm{min}$ ). Based on the retention time of the pollen polysaccharide on the column and the standard pullulan molecular weight curve of the column, the molecular weight of WPPs was calculated.

\subsection{Antitumor Activities of the CF1 of WPPs In Vitro}

\subsubsection{Cell Culture}

Human androgen-independent DU145 cell were bought from Stem Cell Bank, Chinese Academy of Sciences (Shanghai, China). Cells were cultured in DMEM, supplemented with 10\% fetal bovine serum and $1 \%$ penicillin-streptomycin at $37{ }^{\circ} \mathrm{C}$ in a humidified $5 \% \mathrm{CO}_{2}$ incubator (Thermo Fisher Scientific, Shanghai, China). These cells were maintained in the appropriate medium and passaged when cells cover $90 \%$ of the bottom of the culture flask.

\subsubsection{Cell Proliferation Assay}

Cell proliferation was measured by an MTT assay. Briefly, exponentially growing cells were made into cell suspensions at a concentration of $1 \times 10^{5} / \mathrm{mL}$, then $100 \mu \mathrm{L}$ of the cells were seeded into a 96-well plate $\left(1 \times 10^{4} /\right.$ well $)$, an additional $100 \mu \mathrm{L}$ of fresh DMEM medium was added. After the 96-well plate was maintained at $37{ }^{\circ} \mathrm{C}$ with $5 \% \mathrm{CO}_{2}$ in a humidified $\mathrm{CO}_{2}$ incubator for $24 \mathrm{~h}$, different concentrations $(0,125,250,500 \mu \mathrm{g} / \mathrm{mL})$ of CF1 of WPPs were then added into a 96-well plate and to the control group $(0 \mu \mathrm{g} / \mathrm{mL})$ was also added an equal volume of medium and incubated for $24 \mathrm{~h}$. Following incubation, MTT solution $(50 \mu \mathrm{L}, 1 \mathrm{mg} / \mathrm{mL})$ was added and further incubated for another $4 \mathrm{~h}$. The medium containing MTT in the well was discarded, and then $150 \mu \mathrm{L}$ of dimethylsulfoxide 
(DMSO) was added and homogenized thoroughly at room temperature for $10 \mathrm{~min}$ to fully dissolve the crystals. The absorbance of the cells was determined in a full-wavelength micoplate reader (at $550 \mathrm{~nm}$ ). All experiments were performed at least three times and were calculated using average results. The inhibition rate was calculated by the following formula:

$$
\text { Proliferation rate }=\left(\frac{O D_{\text {treated }}}{O D_{\text {control }}}\right) \times 100 \%
$$

\subsubsection{Tunel Assay}

The apoptosis was assessed by Tunel assay. Exponentially growing cells were collected, and the density adjusted to $1 \times 10^{5} / \mathrm{mL}$, inoculated in $1 \mathrm{~mL}$ per well in a 6-well plate, until the cells adhered to the culture flask. Then, $1 \mathrm{~mL}$ medium containing different concentrations of CF1 of WPPs was added; the control group was added to the same volume of fresh medium, and incubated for $24 \mathrm{~h}$. After the treatment, cells were fixed with $4 \%$ paraformaldehyde for $30 \mathrm{~min}$ at room temperature, and then washed with PBS three times. After washing, they were incubated with $3 \% \mathrm{H}_{2} \mathrm{O}_{2}$-methanol for $10 \mathrm{~min}$ at room temperature then washed with PBS 3 times. Fixed cells were then permeabilized with $0.1 \%$ Triton X-100 for $10 \mathrm{~min}$ on ice. After washing, the Tunel reaction mixture was prepared, the treatment groups were mixed with enzyme solution $(50 \mu \mathrm{L})$ and fluorescein-labeled dUTP solution $(450 \mu \mathrm{L})$; however, only $50 \mu \mathrm{L}$ fluorescein-labeled dUTP solution was added to the control group and incubated in a wet box for $1 \mathrm{~h}$ at $37^{\circ} \mathrm{C}$. This was followed by washing with PBS and DAPI was added for $5 \mathrm{~min}$. Finally, the apoptotic cells were viewed and counted by a fluorescent microscope (Olympus BX43, Tokyo, Japan).

\subsubsection{Flow Cytometry Assay}

The DU-145 cells were treated with different concentrations of CF1 of WPPs and the cell apoptotic ratio was determined by Annexin V-FITC and PI staining followed by analysis with flow cytometry. Early and late apoptotic changes in different cells were determined using an Annexin V-FITC/PI Apoptosis Detection Kit (BestBio, Shanghai, China) following the manufacturer's instructions. Cells $\left(1 \times 10^{6} / \mathrm{mL}\right)$ were collected and washed twice with precooled PBS. The samples were resuspended in $400 \mu \mathrm{L} 1 \times$ Annexin V; To the cell suspension was added $5 \mu \mathrm{L}$ Annexin V-FITC staining solution, gently mixed and incubated for $15 \mathrm{~min}$ at $2{ }^{\circ} \mathrm{C}$ to $8^{\circ} \mathrm{C}$ in the dark, then $10 \mu \mathrm{L}$ PI staining solution was added and gently mixed at $2{ }^{\circ} \mathrm{C}$ to $8{ }^{\circ} \mathrm{C}$ in the dark, incubated for 5 min and immediately tested with a FACS Calibur flow cytometer (BD Biosciences, San Joes, CA, USA).

\subsection{Statistical Analysis}

All experiments were repeated at least three times, statistical analysis was carried out using SPSS 17.0 statistical software. All values were presented as the mean $\pm \mathrm{SD}$, multi-group mean comparison was analyzed by one-way variance, and pairwise comparison was performed by LSD test. Significance difference was set at $p<0.05$.

\section{Conclusions}

In summary, a polysaccharide CF1 with molecular weights of $1540.10 \pm 48.78 \mathrm{kDa}$, was successfully isolated from wolfberry pollen through DEAE-52 cellulose and Sephadex G-100 chromatography. Monosaccharide analysis revealed that the CF1 of WBPPs was composed of mannose, glucuronic acid, galacturonic acid, xylose, galactose, arabinose, and trehalosein in a molar ratio of 0.68:0.59:0.27:0.24:0.22:0.67:0.08. The biological activity of the CF1 of WPPs exhibited a dose-dependent antitumor effect on the DU145 prostate cancer cell. The antitumor activity of CF1 was related to apoptosis in vitro. However, the mechanism of how the CF1 of WPPs induces apoptosis is unclear; we need further research and exploration. In a word, CF1 of WPPS should be considered as a potential source of antitumor functional food or agent. 
Author Contributions: F.C. performed some of the experiments, analyzed the data, and wrote the manuscript. L.R. designed and performed some of the experiments and wrote some of the manuscript. J.M., L.L., B.J., X.L. performed some of the experiments. Y.Y. and Y.C. supervised the experimental work. All authors read and approved the final manuscript.

Funding: This research was funded by National Natural Science Foundation of China (81360424), by Pilot Project by Ningxia Academy of Agriculture and Forestry Science (NKYJ-18-22 and QCYC-2018-05) and by Ningxia Natural Science Foundation (2018AAC03069).

Acknowledgments: The authors gratefully acknowledge financial support from the China Scholarship Council and Ningxia Medical University.

Conflicts of Interest: The authors declare no conflict of interest.

\section{References}

1. Toren, P.; Zoubeidi, A. Targeting the PI3K/Akt pathway in prostate cancer: Challenges and opportunities (review). Int. J. Oncol. 2014, 45, 1793-1801. [CrossRef] [PubMed]

2. Žilić, S.; Vančetović, J.; Janković, M.; Maksimović, V. Chemical composition, bioactive compounds, antioxidant capacity and stability of floral maize (Zea mays L.) pollen. J. Funct. Foods. 2014, 10, 65-74. [CrossRef]

3. Habib, F.K.; Ross, M.; Buck, A.C.; Ebeling, L.; Lewenstein, A. In vitro evaluation of the pollen extract cernitin T60, in the regulation of prostrate cell growth. Br. J. Urol. 1990, 66, 393-397. [CrossRef] [PubMed]

4. Li, Y.F.; Tang, L.P.; He, R.R.; Xu, Z.; Xiang, F.J.; Su, W.W.; Hiroshi, K. Anthocyanins extract from bilberry enhances the therapeutic effect of pollen of Brassica napus L. on stress-provoked benign prostatic hyperplasia in restrained mice. J. Funct. Foods 2013, 5, 1357-1365. [CrossRef]

5. Monden, K.; Tsugawa, M.; Ninomiya, Y.; Ando, E.; Kumon, H.A. Japanese version of the National Institutes of Health Chronic Prostatitis Symptom Index (NIH-CPSI, Okayama version) and the clinical evaluation of cernitin pollen extract for chronic non-bacterial prostatitis. Nihon Hinyokika Gakkai Zasshi 2002, 93, 539-547. [CrossRef] [PubMed]

6. Brecker, L.; Wicklein, D.; Moll, H.; Fuchs, E.C.; Becker, W.M.; Petersen, A. Structural and immunological properties of arabinogalactan polysaccharides from pollen of timothy grass (Phleumpratense L.). Carbohydr. Res. 2005, 340, 657-663. [CrossRef] [PubMed]

7. Yang, X.; Guo, D.; Zhang, J.; Wu, M. Characterization and antitumor activity of pollen polysaccharide. Int. Immunopharmacol. 2007, 7, 427-434. [CrossRef] [PubMed]

8. Wang, B.; Diao, Q.; Zhang, Z.; Liu, Y.; Gao, Q.; Zhou, Y.; Li, S. Antitumor activity of bee pollen polysaccharides from Rosa rugosa. Mol. Med. Rep. 2013, 7, 1555-1558. [CrossRef] [PubMed]

9. Tyliszczak, B.; Drabczyk, A.; Kudłacik-kramarczyk, S.; Grabowska, B.; Kędzierska, M. Physicochemical properties and cytotoxicity of hydrogels based on Beetosan ${ }^{\circledR}$ containing sage and bee pollen. Acta Biochim. Pol. 2017, 64, 709-712. [CrossRef] [PubMed]

10. Yue, G.; Li, X.; Sun, M.; Su, F. Immunomodulatory effects of sulfated polysaccharides of pine pollen on mouse macrophages. Int. J. Biol. Macromol. 2016, 91, 846-855. [CrossRef]

11. Luo, Q.; Li, J.; Cui, X.; Yan, J.; Zhao, Q.; Xiang, C. The effect of Lycium barbarum, polysaccharides on the male rats reproductive system and spermatogenic cell apoptosis exposed to low-dose ionizing irradiation. J. Ethnopharmacol. 2014, 154, 249-258. [CrossRef] [PubMed]

12. Gong, G.P.; Fan, J.B.; Sun, Y.J.; Wu, Y.M.; Liu, Y.; Sun, W.; Zhang, Y.; Wang, Z.F. Isolation, structural characterization, and antioxidativity of polysaccharide LBLP5-A from Lycium barbarum, leaves. Process. Biochem. 2015, 51, 314-324. [CrossRef]

13. Mao, F.; Xiao, B.; Jiang, Z.; Zhao, J.; Huang, X.; Guo, J. Anticancer effect of Lycium barbarum, polysaccharides on colon cancer cells involves G0/G1 phase arrest. Med. Oncol. 2011, 28, 121-126. [CrossRef] [PubMed]

14. Chen, S.; Liang, L.; Wang, Y.; Diao, J.; Zhao, C.; Chen, G.; He, Y.; Luo, C.; Wu, X.; Zhang, Y. Synergistic immunotherapeutic effects of Lycium barbarum polysaccharide and interferon- $\alpha 2 \mathrm{~b}$ on the murine Renca renal cell carcinoma cell line in vitro and in vivo. Mol. Med. Rep. 2015, 12, 6727-6737. [CrossRef] [PubMed]

15. Qian, Z.; Lv, X.; Tao, W.; Ma, Q.; Teng, A.; Zhang, Y.; Zhang, M. Composition of Lycium barbarum polysaccharides and their apoptosis-inducing effect on human hepatoma SMMC-7721 cells. Food Nutr. Res. 2015, 59, 28696. [CrossRef] 
16. Miao, Y.; Xiao, B.; Jiang, Z.; Guo, Y.; Mao, F.; Zhao, J.; Huang, X.; Guo, J. Growth inhibition and cell-cycle arrest of human gastric cancer cells by Lycium barbarum polysaccharide. Med. Oncol. 2010, 27, 785-790. [CrossRef] [PubMed]

17. Li, B.; Wei, K.; Yang, S.; Yang, Y.; Zhang, Y.; Zhu, F.; Wang, D.; Zhu, R. Immunomodulatory effects of Taishan Pinus massoniana pollen polysaccharide and propolis on immunosuppressed chickens. Microb. Pathog. 2015, 78, 7-13. [CrossRef] [PubMed]

18. Li, X.; Gong, H.; Yang, S.; Yang, L.; Fan, Y.; Zhou, Y. Pectic bee pollen polysaccharide from rosarugosa alleviates diet-induced hepatic steatosis and insulin resistance via induction of AMPK/mTOR-mediated autophagy. Molecules 2017, 22, E699. [CrossRef] [PubMed]

19. Xu, C.; Liu, Y.; Yuan, G.; Guan, M. The contribution of side chains to antitumor activity of a polysaccharide from Codonopsispilosula. Int. J. Biol. Macromol. 2012, 50, 891-894. [CrossRef] [PubMed]

20. Bao, X.L.; Yuan, H.H.; Wang, C.Z.; Fan, W.; Lan, M.B. Polysaccharides from Cymbopogoncitratus with antitumor and immunomodulatory activity. Pharm. Biol. 2015, 53, 117-124. [CrossRef] [PubMed]

21. Sun, X.; Liu, N.; Wu, Z.; Feng, Y.; Meng, X. Anti-tumor activity of a polysaccharide from blueberry. Molecules 2015, 20, 3841-3853. [CrossRef] [PubMed]

22. Fan, Y.; Lin, M.; Luo, A.; Chun, Z.; Luo, A. Characterization and antitumor activity of a polysaccharide from sarcodiaceylonensis. Molecules 2014, 19, 10863-10876. [CrossRef] [PubMed]

23. Zhang, X.; Li, S.; Sun, L.; Ji, L.; Zhu, J.; Fan, Y.; Tai, G.; Zhou, Y. Further analysis of the structure and immunological activity of an RG-I type pectin from Panax ginseng. Carbohydr. Polym. 2012, 89, 519-525. [CrossRef] [PubMed]

24. Wu, M.; Luo, X.; Xu, X.; Wei, W.; Yu, M.; Jiang, N.; Ye, L.; Yang, Z.; Fei, X. Antioxidant and immunomodulatory activities of a polysaccharide from Flammulinavelutipes. J. Tradit. Chin. Med. 2014, 34, 733-740. [CrossRef]

25. Suabjakyong, P.; Nishimura, K.; Toida, T.; Van Griensven, L.J. Structural characterization and immunomodulatory effects of polysaccharides from Phellinuslinteus and Phellinusigniarius on the IL-6/IL-10 cytokine balance of the mouse macrophage cell lines (RAW 264.7). Food Funct. 2015, 6, 2834-2844. [CrossRef] [PubMed]

26. Kouakou, K.; Schepetkin, I.A.; Yapi, A.; Kirpotina, L.N.; Jutila, M.A.; Quinn, M.T. Immunomodulatory activity of polysaccharides isolated from Alchorneacordifolia. J. Ethnopharmacol. 2013, 146, 232-242. [CrossRef] [PubMed]

27. Cör, D.; Knez, Ž.; Knez Hrnčič, M. Antitumour, antimicrobial, antioxidant and antiacetylcholinesterase effect of Ganoderma Lucidum terpenoids and polysaccharides: A review. Molecules 2018, 23, 649. [CrossRef] [PubMed]

28. Zhu, Z.Y.; Dong, F.; Liu, X.; Qian, L.; Yang, Y.; Fei, L.; Chen, L.; Wang, T.; Wang, Z.; Zhang, Y. Effects of extraction methods on the yield, chemical structure and anti-tumor activity of polysaccharides from Cordyceps gunnii, mycelia. Carbohydr. Polym. 2016, 140, 461-471. [CrossRef] [PubMed]

29. Li, X.; Jiao, L.L.; Zhang, X.; Tian, W.M.; Chen, S.; Zhang, L.P. Anti-tumor and immunomodulating activities of proteoglycans from mycelium of Phellinusnigricans and culture medium. Int. Immunopharmacol. 2008, 8, 909-915. [CrossRef] [PubMed]

30. Bao, H.H.; Choi, W.S.; You, S. Effect of sulfated modification on the molecular characteristics and biological activities of polysaccharides from Hypsizigusmarmoreus. Biosci. Biotechnol. Biochem. 2010, 74, 1408-1414. [CrossRef] [PubMed]

31. Lombard, Y.; Giaimis, J.; Makaya-Kumba, M.; Fonteneau, P.; Poindron, P. A new method for studying the binding and ingestion of zymosan particles by macrophages. J. Immunol. Methods 1994, 174, 155-165. [CrossRef]

32. Zheng, Y.; Hao, M.; Nan, H.; Jeff, I.; Zhou, Y.; Gao, Y. Relationship of chemical composition and cytotoxicity of water-soluble polysaccharides from lentinus edodes fruiting bodies. Pak. J. Pharm. Sci. 2015, 28, 1069-1074. [PubMed]

33. Zong, A.; Cao, H.; Wang, F. Anticancer polysaccharides from natural resources: A review of recent research. Carbohydr. Polym. 2012, 90, 1395-1410. [CrossRef] [PubMed]

34. Xu, Y.; Zhu, J.Y.; Lei, Z.M.; Wan, L.J.; Zhu, X.W.; Ye, F.; Tong, Y.Y. Anti-proliferative effects of paeonol on human prostate cancer cell lines DU145 and PC3. J. Physiol. Biochem. 2017, 73, 157-165. [CrossRef] [PubMed] 
35. Choo, G.S.; Lee, H.N.; Shin, S.A.; Kim, H.J.; Jung, J.Y. Anticancer effect of fucoidan on DU-145 prostate cancer cells through inhibition of PI3K/Akt and MAPK pathway expression. Mar. Drugs 2016, 14, E126. [CrossRef] [PubMed]

36. Luo, Q.; Li, Z.N.; Yan, J.; Zhu, F.; Xu, R.J.; Cai, Y.Z. Lycium barbarum polysaccharides induce apoptosis in human prostate cancer cells and inhibits prostate cancer growth in a xenograft mouse model of human prostate cancer. J. Med. Food 2009, 12, 695-703. [CrossRef] [PubMed]

37. Zhang, M.; Chen, H.; Huang, J.; Li, Z.; Zhu, C.; Zhang, S. Effect of Lycium barbarum polysaccharide on human hepatoma QGY7703 cells: Inhibition of proliferation and induction of apoptosis. Life Sci. 2005, 76, 2115-2124. [CrossRef] [PubMed]

38. Wang, J.; Zhao, X.Z.; Qi, Q.; Tao, L.; Zhao, Q.; Mu, R.; Gu, H.Y.; Wang, M.; Feng, X.; Guo, Q.L. Macranthoside $\mathrm{B}$, a hederageninsaponin extracted from Loniceramacranthoides and its anti-tumor activities in vitro and in vivo. Food Chem. Toxicol. 2009, 47, 1716-1721. [CrossRef] [PubMed]

39. Shen, H.Y.; Li, L.Z.; Xue, K.C.; Hu, D.D.; Gao, Y.J. Antitumor activity of fucoidan in anaplastic thyroid cancer via apoptosis and anti-angiogenesis. Mol. Med. Rep. 2017, 15, 2620-2624. [CrossRef] [PubMed]

40. Chang, J.S.; Kuo, H.P.; Chang, K.L.; Kong, Z.L. Apoptosis of hepatocellular carcinoma cells induced by nanoencapsulated polysaccharides extracted from antrodia camphorata. PLoS ONE 2015, 10, e0136782. [CrossRef] [PubMed]

41. Zhang, X.Y.; Sun, K.; Zhu, Q.; Song, T.; Liu, Y. Ginseng polysaccharide serves as a potential radiosensitizer through inducing apoptosis and autophagy in the treatment of osteosarcoma. Kaohsiung J. Med. Sci. 2017, 33, 535-542. [CrossRef] [PubMed]

42. Yu, X.H.; Liu, Y.; Wu, X.L.; Liu, L.Z.; Fu, W.; Song, D.D. Isolation, purification, characterization and immunostimulatory activity of polysaccharides derived from American ginseng. Carbohydr. Polym. 2017, 156, 9-18. [CrossRef] [PubMed]

43. Yuan, Q.; Xie, Y.; Wang, W.; Yan, Y.; Ye, H.; Jabbar, S.; Zeng, X. Extraction optimization, characterization and antioxidant activity in vitro of polysaccharides from mulberry (Morus alba L.) leaves. Carbohydr. Polym. 2015, 128, 52-62. [CrossRef] [PubMed]

Sample Availability: Samples of the compound CF1 is available from the authors.

(c) 2018 by the authors. Licensee MDPI, Basel, Switzerland. This article is an open access article distributed under the terms and conditions of the Creative Commons Attribution (CC BY) license (http:/ / creativecommons.org/licenses/by/4.0/). 